\title{
The mediating effect of job happiness on the relationship between job satisfaction and employee performance and turnover intentions: A case study on the oil and gas industry in the United Arab Emirates
}

\author{
Waleed Al-Ali \\ Ali Ameen \\ Osama Isaac \\ Gamal S. A. Khalifa \\ Ahmed Hamoud Shibami \\ Faculty of Business and Accountancy \\ Lincoln University College, Selangor, Malaysia
}

Key words

Job satisfaction; job performance; job happiness; turnover intention; United Arab Emirates

\begin{abstract}
This study aims to examine the mediating effect of job happiness factor on the relationship between job satisfaction and both employees' performance and turnover intentions in oil and gas industry in the United Arab Emirates (UAE). The study utilized a total of 722 usable questionnaires that were administered to respondents in oil and gas industry in the United Arab Emirates. This study adopted structural equation modelling (SEM) approach to analyze these relationships. The Analysis of Data revealed that job satisfaction factor has a significant direct positive relationship with both factors the employees' performance and the job happiness, while it has a negative insignificant relationship with employees' turnover intention. On the other hand, the Job happiness displays a significant positive direct effect on job performance, but it records a significant negative effect on employee turnover intention. Results show that job happiness plays a mediating role between job satisfaction and employee performance and turnover intention. These findings may guide the implementation of policies by human resources or other organization managements in the UAE Oil and Gas industry. For instance, they may use job happiness (mental well-being) as a predictor of employee behaviors and then formulate recruitment policies that will help maintain employee happiness and satisfaction, thereby helping in employee retention.
\end{abstract}

Corresponding author: Ali Ameen

Email addresses for the corresponding author: aliameen.academy@gmail.com

First submission received: $7^{\text {th }}$ May 2018

Revised submission received: $3^{\text {rd }}$ February 2019

Accepted: 2ns April 2019

\section{Introduction}

Human capital is considered one of the most dynamic assets for the growth and development of any organization. Human capital makes other assets useful and valuable in any organization and subsequently generates the best return for the organization. Thus, to obtain improved human capital, the organization and its management should conduct great interchanges and movements. If employees are satisfied and happy with the actions of their organization management, then they will do their best for the best of the organization. High levels of happiness and satisfaction among employees indicates high returns for the organization (Adel Haddad, Ali Ameen, \& Muaadh Mukred, 2018). Thus, the issue of employee happiness and satisfaction is important to any organization management and is recognized by numerous research conducted by several scholars, academicians, and management leaders.

Existing literature on human resources and organization behaviors identified various job satisfaction determinants, such as pay or level income, promotion opportunities, co-workers, job conditions, communications, personal growth, security, and working environments (Wu, X., 2012; Cook, 2015). Job satisfaction is also classified into two: affective and cognitive job satisfaction. Affective job satisfaction increases happiness toward the job, whereas cognitive job satisfaction helps in the logical 
evaluation of facets related to the job. Job satisfaction has a direct effect on levels of absenteeism, commitment, performance, and productivity (Khan et al., 2011) and helps improve employee retention, thereby reducing the cost of hiring new employees (Murray, 1999).

In addition, the turnover intention of employees remains a critical issue for human resources and organization managements because of its adverse consequences for effective organizational functioning. A recent literature review of organization behaviors revealed that the turnover rate of employees within organizations increases day by day. This phenomenon may be attributed to organizations that focus more on large profitability and return than on the satisfaction level of employees (Abdulbaqi Ameen \& Ahmad, 2011). This priority may create non-satisfaction among employees and consequently increase the rate of employee turnover intention. As a result, organization resources and time will merely be wasted on various activities. These resources and activities include costs involved in the selection of employees, the recruitment process, and employee training for enhancing their skills (Kessler-Ladelsky \& Catana, 2013). This finding further results in the interruption of the organization's continuous work and hampers the organization's genial performance (Al-Maamari et al., 2018). Therefore, valuable employees of the organization should be retained.

Prior research in human resource and organization behaviors endeavored to test direct relationships between job satisfaction and employee performance and turnover intention (Fatah, Kamal Abdel, a Kamal Abdel Fatah, 2017). They found evidence of a positive relationship between job satisfaction and employee performance, as well as a negative relationship between job satisfaction and employee turnover intention. However, knowledge on the role of the mediating effect of employee happiness (mental well-being) between these relationships remains lacking. Happiness provides several positive benefits for not only the individuals themselves, but also for those whom they meet (Wright \& Cropanzano, 2004). Many researchers believe that happiness should lead to improved job performance in any organization (Wright \& Cropanzano, 2004). Therefore, this study attempts to examine the role of the mediating effect of job happiness (mental well-being) on the relationship between job satisfaction and employee performance and turnover intentions in the oil and gas industry in the United Arab Emirates (A. A. Ameen \& Ahmad, 2012).

\section{Literature Review}

\subsection{Job Satisfaction and Job Performance}

The idea that job satisfaction and job performance are positively associated with each other is supported by a number of previous research. For instance, Vroom (1964), Opkara (2002), Guest (2004), Silla et al. (2005), Schermerhorn et al. (2005), Spector, (2008), and Davar and RanjuBala (2011) investigated the relationship between job satisfaction and job performance; they found a direct association between the two. Researchers of these studies suggest that organizations should focus on keeping their employees satisfied and happy to increase productivity. Existing literature also confirmed that satisfied employees have improved performance and they greatly contribute to the overall achievement of the organization (Davar \& RanjuBala, 2011). By contrast, studies also concluded that employees who are unsatisfied with their position will not perform effectively, which may become one of the major barriers to the success of the organization. Therefore, the human resource management of any organization should enhance focus on determining or exploring ways in which the satisfaction of employees can be improved to achieve their business goals. Based on this discussion, a hypothesis was developed to test the relationship between both variables for organizations in the UAE oil and gas industry. The hypothesis is as follows.

H1: A direct positive relationship exists between job satisfaction and job performance.

\subsection{Job Satisfaction and Turnover Intentions}

The relationship between job satisfaction and turnover intentions was explored in many previous studies. Most scholars agree that job satisfaction and turnover intention are negatively related to each other (Carmeli, 1991; DeConinck \& Stilwell, 2004; O'Reilly et al., 2005), and turnover intention is inversely related to job satisfaction. In other words, a low job satisfaction indicates increased turnover intention (Medina, 2012). Researchers also agree that the lack of employee job satisfaction in an organization leads to absenteeism, lack of commitment, and an increase in turnover rate. Employee job satisfaction was also found to be a good predictor of retention of a highly skilled and experienced labor force in an 
organization (Alexander, Litchtenstein, \& Hellman, 1998). A second hypothesis was developed to critically explore the relationship between the two variables in the context of organizational behaviors in the UAE oil and gas industry (Al-Obthani \& Ameen, 2018).

H2: A negative relationship exists between job satisfaction and turnover intention.

\subsection{Psychological Well-Being (Happiness) and Job Performance}

The well-being or happiness of an employee is interconnected with the job performance of employees (Daniels \& Harris, 2000). Researchers found that employees who exhibit happiness characteristics are the highest performing and most efficient workers (Daniels \& Harris, 2000). The happiest employees take a reduced number of leaves of absences and display loyal behavior for an extended period of time, which eventually improves their job performance (Abd-Elaziz, Aziz, Khalifa, \& Abdel-Aleem, 2015). Happiness in the workplace is a strong feeling associated with employees in which they are proud of themselves, thereby resulting in improved performance in the organization (Daniels \& Harris, 2000; Rashed Shtait Hamad AlShamsi, Ali Ameen, 2017). Therefore, organizations should focus on developing and enhancing happy characteristics of employees to help improve employee performance in the most effective manner and achieve increased return (Argyle, 1989). The hypothesis of the relationship or association between psychological well-being or happiness and job performance is as follows. H3: A positive relation exists between psychological well-being or happiness and job performance.

\subsection{Psychological Well-Being (Happiness) and Turnover Intention}

Happy employees can potentially understand the goals and objectives of the organization and display a certain set of behaviors in terms of tangible outcomes and physiological domains (Awang, Ibrahim \& Nor, 2015). Happy employees have reduced turnover intentions because employees are treated fairly and are valued by the organization. This characteristic is one of the most important factors associated with job satisfaction and performance. Therefore, organizations at present place added focus on these aspects along with providing improved working conditions and environments (Judge T. A., Thoresen, Bono \& Patton, 2001). Furthermore, happiness has a collective effect on many factors that reduces turnover intentions (Awang, Ibrahim \& Nor, 2015). The proposed hypothesis for the relationship between psychological well-being or happiness and turnover intention in the current study is stated below.

H4: A negative relation exists between psychological well-being or happiness and turnover intention.

\subsection{Job Satisfaction and Psychological Well-being (Happiness)}

In the most recent years, most modern organization have trying to lay emphasis on the wellbeing of their employees to enhance productivity level. Happiness should be stimulated because it is an indicator of mental well-being and it enhances motivation, job performance, and work consequences (Awang, Ibrahim \& Nor, 2015). Job satisfaction expresses how employees feel about their job and its related aspects (Cook D, 2015) and the extent to which employees like or dislike their job. Therefore, job dissatisfaction and job satisfaction can arise in any given work situation. Job satisfaction represents a combination of positive and negative feelings shown in the workplace, and it is highly associated with the behavior of an employee at the workplace. Various determinants of job satisfaction are rising in number and include pay and level income, promotion opportunities, co-workers, job conditions, communications, personal growth, security, and working environment (Wu, X. 2012; Govender, 2014; Cook, 2015). These determinants of job satisfaction are related to the happiness of employees because it provides them psychological and mental satisfaction. This study aims to determine the direct effect of job satisfaction on physical and mental well-being or happiness and the role of the mediating effect of job happiness on the relationship between job satisfaction and employee performance and turnover intentions in the UAE oil and gas industry (A. Ameen, Almulla, Ali, Al-shibami, \& Ghosh, 2018). Thus, the following hypotheses were developed.

H5: Job Satisfaction has a positive effect on job happiness

H6: Job happiness mediates the positive effect of job satisfaction on job performance.

H7: Job happiness mediates the positive effect of job satisfaction on employee turnover intention. 


\section{Research Method}

\subsection{Overview of the Proposed Research Model}

The preceding literature review supports the following theoretical framework that effectively describes the relationship between variables under the study on the UAE oil and gas industry. The theoretical framework of the study is graphically represented in Figure 1.

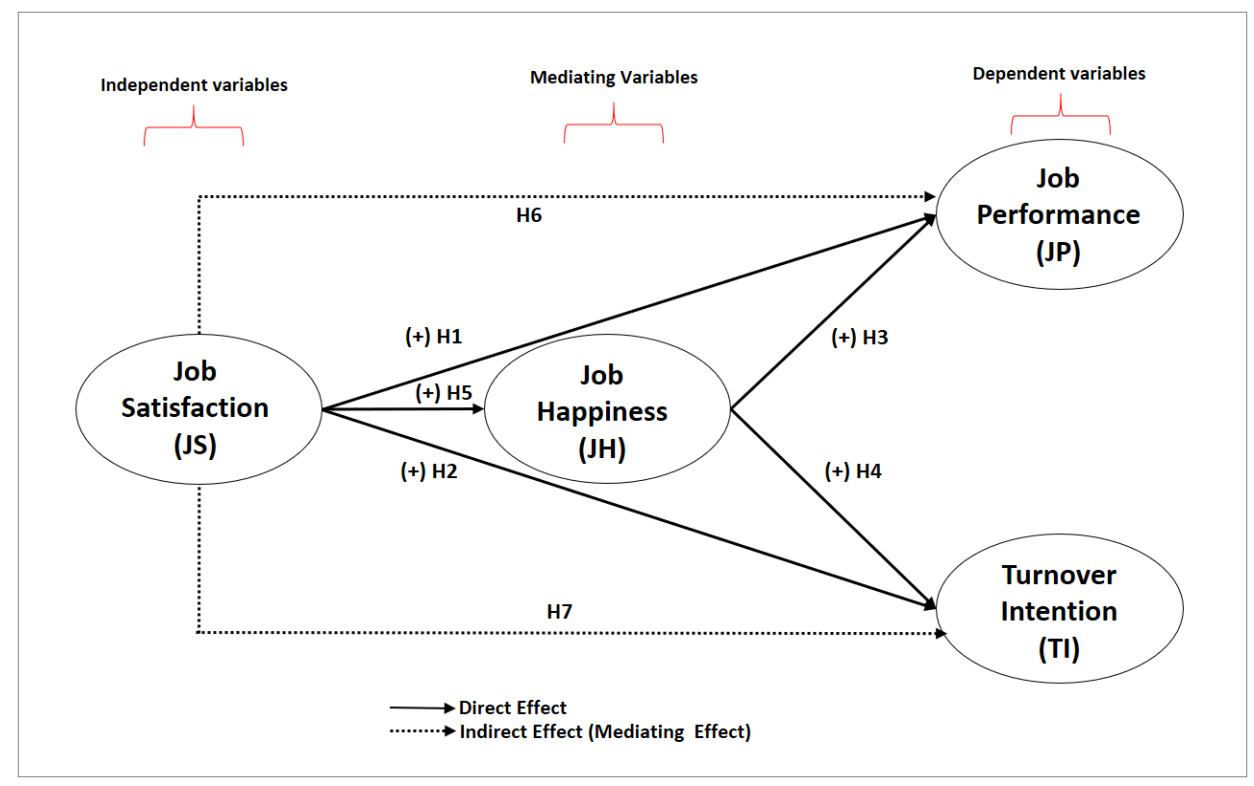

Figure 1: The Proposed Model

\subsection{Data Processing and Methodology}

This study used a quantitative research design for collecting primary data to test the proposed hypotheses. This study adopted the Structural Equation Modeling (SEM) approach using the analysis of moment structures version 23.0 with maximum likelihood estimation. Data analysis was conducted in several stages. In the first stage, the description of demographic characteristic variables of respondents was analyzed. The second stage involved the use of exploratory factor analysis to identify the strength of inter-correlations among variables. In the third stage, confirmatory factor analysis (CFA) was conducted to assess the validity and reliability of variables under study. The final stage employed SEM to test structural relationships between variables and hypotheses.

\section{Result and Discussion \\ 4.1 Response Rate}

The total number of distributed survey questionnaires was 855 . Of the 855 questionnaires, 740 were returned, which represents an $86.5 \%$ response rate. From the returned questionnaires, 18 were excluded from analysis due to outlier cases. Thus, a total of 722 usable questionnaires were utilized, which represents an $84.4 \%$ response rate. The sample size of $n=722$ was considered sufficient for this study. The study sample size ( $\mathrm{n}=722)$ achieved a ratio of 10:1 as recommended by Hair et al. (1998) and Kline (2005).

\subsection{Descriptive Analysis}

Results of descriptive analysis are displayed in Table 1. The table shows that respondents of this study consist of 212 females (28.6\%) and 528 males (71.4\%). The average age of the sample in this study was divided into four categories. A total of 316 respondents $(42.9 \%)$ were aged 25-35 years old, which indicates that most oil and gas industry employees are young people. Respondents who were 36-50 years old and more than 50 years old comprise $106(14.3 \%)$.

In terms of nationality, the majority of respondents (528) were Emiratis, representing $71.4 \%$ of total respondents, followed by non-Emiratis (212), representing $28.6 \%$. Results also indicate that most respondents (507) had a postgraduate degree at $68.6 \%$ of the total. A total of 212 respondents $(28.6 \%)$ had a bachelor's degree, and $21(2.9 \%)$ had a diploma. With regards to the designation of respondents, the majority of respondents (296) were executives, which constitute $40 \%$ of the total respondents. A total of 
183 respondents $(24.7 \%)$ were managers, and $155(21 \%)$ were senior executives. The designation with the smallest number of respondents is that of senior managers, with 106 respondents $(14.3 \%)$.

Results also show that the period of employment in present organizations with the highest percentage of respondents is $5-10$ years, with $57.1 \%$ (423 respondents), and that with the lowest is 11-15 years, with $25.7 \%$ (190 respondents). Only $2.9 \%$ or 21 respondents have been employed in their present organizations for more than 15 years.

Table 1 Descriptive Statistics for Demographic Variables

\begin{tabular}{l|lll}
\hline Particulars & Demographic & Frequency & Percent (\%) \\
\hline Gender & Male & 528 & 71.4 \\
Age & Female & 212 & 28.6 \\
& Less than 25 & 212 & 28.6 \\
& 25-35 Years & 316 & 42.9 \\
& 36-50 Years & 106 & 14.3 \\
Nationality & More than 50 & 106 & 14.3 \\
Qualification & Emirati & 528 & 71.4 \\
& Non-Emirati & 212 & 28.6 \\
Designation & Diploma & 21 & 2.9 \\
& Bachelor's degree & 212 & 28.6 \\
& Postgraduate degree & 507 & 68.6 \\
Period of employment in the present & Executive & 296 & 40 \\
organization & Senior Executive & 155 & 21 \\
& Manager & 183 & 24.7 \\
& Senior Manager & 106 & 14.3 \\
& Less than 5 years & 106 & 14.3 \\
& 5-10 years & 423 & 57.1 \\
& 11-15 years & 190 & 25.7 \\
\hline
\end{tabular}

\subsection{Exploratory Factor Analysis (EFA)}

Principal axis factoring was conducted with Promax oblique rotation. Two types of rotation may be used in EFA: orthogonal and oblique rotations. Some scholars argue that oblique rotation is always appropriate because factor intercorrelations are the norm in social sciences; moreover, orthogonal and oblique rotations would yield the same result if the factors happen to be uncorrelated (Costello \& Osborne, 2005). Regarding significant factor loadings for every item, the present study follows the criteria of Hair, Black, Babin, and Anderson (2010) based on sample size. With the sample size of this study at 722 for the EFA, significant factor loadings are at 0.40 . This study used a fixed number of factors for extraction. Results regarding the statistical assumption for EFA are as follows.

- The sample size is 722, which is enough to conduct EFA (Tabachnick \& Fidell, 2007).

- Bartlett's test of sphericity is significant at $p<0.001$ (Field, 2013).

- The Kaiser-Meyer-Olkin value is 0.903 which is remarkable (Kaiser, 1974; Hutcheson \& Sofroniou, 1999).

- The communalities value for every item is $>0.5$ (Field, 2013).

- Total explained variance is $70.14 \%$, which is $>50 \%$ (Podsakoff \& Organ, 1986).

- The variance for the first factor is $34.08 \%$, which is $<50 \%$ (Podsakoff \& Organ, 1986).

Factor analysis results indicate nine factors with an eigenvalue greater than one: job performance with 12 items (JP1-JP12), optimism with nine items (JHO1-JHO9), job happiness in terms of passive moods with four items (JHP1-JHP4), job happiness in terms of social relationships with five items (JHS1JHS5), co-worker satisfaction with four items (JSC1-JSC4), employee turnover intention with six items (ETI1-ETI6), supervisor satisfaction with four items (JSS1-JSS4), promotion satisfaction with four items (JSM1-JSM4), and pay satisfaction with four items (JSP1-JSP4).

After EFA, 52 items in the questionnaire were used to determine and investigate the relationship of factors in this study. All items have a loading of more than 0.50 and ranged from 0.549 to 0.895 . Thus, this 
study may continue with further analysis without dropping any other items because their factor loading is more than the required amount.

\subsection{Measurement model assessment and CFA \\ 4.4.1 Model Fit Indicators}

As shown in Table 2 and Figure 2, all goodness-of-fit indices exceed their respective common acceptance levels as suggested by previous research. This finding demonstrate that the measurement model exhibited a fairly good fit with the data collected $\left(\mathrm{X}^{2} / \mathrm{df}=4.476, \mathrm{CFI}=0.912, \mathrm{RMSEA}=0.069\right.$, $\mathrm{GFI}=0.9901$, AGFI=0.887, NFI=0.913, TLI=0.944, $\mathrm{IFI}=0.980, \mathrm{PNFI}=0.791$, and PGFI=0.725). Absolute fit indices show that the chi-square is insignificant. However, the model still fits because when large samples are used, the chi-square statistic nearly always rejects the model (Bentler \& G. Bonnet, 1980; Jöreskog \& Sörbom, 1993). The chi-square is sensitive to sample size $>200$ (Byrne, 2010); the sample size in this study is 722. In this case, the model may be considered acceptable (Schumacker \& Lomax, 2004; Lee \& Kim, 2007), which indicates that the model employed in this research is a good fit for the collected data. Therefore, evaluation of psychometric properties of the measurement model in terms of construct reliability, indicator reliability, convergent validity, and discriminant validity may be pursued.

Table 2: Goodness-of-fit indices for the measurement model

\begin{tabular}{|c|c|c|c|c|}
\hline Fit Index & Cited & $\begin{array}{l}\text { Admissibilit } \\
\mathrm{y}\end{array}$ & Result & Fit (Yes/No) \\
\hline$\overline{X^{2}}$ & & & 5600.079 & \\
\hline DF & & & 1251 & \\
\hline P value & & $>.05$ & .000 & No \\
\hline $\mathrm{X}^{2} / \mathrm{DF}$ & (Kline, 2010) & $1.00-5.00$ & 4.476 & Yes \\
\hline RMSEA & (Steiger, 1990) & $<.08$ & .069 & Yes \\
\hline SRMR & (Hu \& Bentler, 1999) & $<.08$ & .033 & Yes \\
\hline GFI & (Jöreskog \& Sörbom, 1993) & $>.90$ & .901 & Yes \\
\hline AGFI & (Jöreskog \& Sörbom, 1993) & $>.80$ & .887 & Yes \\
\hline NFI & (Bentler \& G.Bonnet, 1980) & $>.80$ & .913 & Yes \\
\hline PNFI & (Bentler \& G.Bonnet, 1980) & $>.05$ & .791 & Yes \\
\hline IFI & (Bollen, 1990) & $>.90$ & .922 & Yes \\
\hline TLI & (Tucker \& Lewis, 1973) & $>.90$ & .944 & Yes \\
\hline CFI & (Byrne, 2010) & $>.90$ & .912 & Yes \\
\hline PGFI & (James, Muliak \& Brett, 1982) & $>.50$ & .725 & Yes \\
\hline
\end{tabular}

Note: $X^{2}=$ Chi-Square, DF $=$ Degree of freedom, GFI $=$ Goodness-of-fit index, NFI $=$ Normed fit index, IFI = Increment fit index, TLI $=$ Tucker-Lewis coefficient index, CFI $=$ Comparative fit index, RMSEA = Root Mean Square Error of Approximation, SRMR = Standardized Root Mean Square Residual, PNFI = Parsimony Normed Fit Index, AGFI = Adjusted Goodness-of-fit index. Indices in bold are recommended because they are frequently reported in literature (Awang, 2014) 


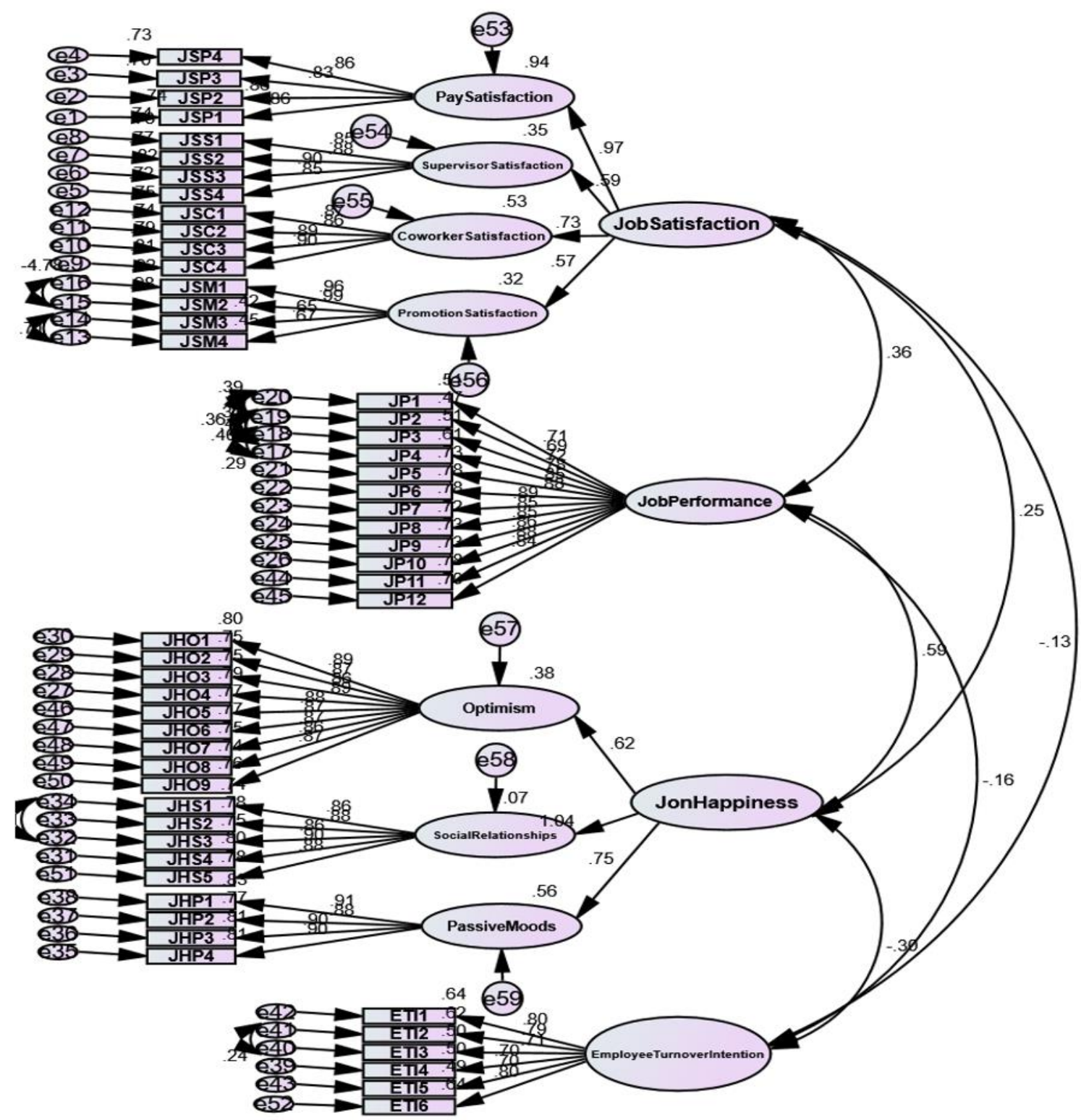

Figure 2: Full Measurement Model under Study

\subsubsection{Reliability and Validity Assessment}

To improve the measurement of model fit, some items with factor loadings lower than .50 and high error were excluded using Modification Indices (MI) to achieve additional goodness-of-fit. Further inspection of (MI) indicated that errors of items (JSM1 $\leftrightarrow$ JSM2), (JSM3 $\leftrightarrow$ JSM4), (JP1 $\leftrightarrow$ JP2), (JP3 $\leftrightarrow$ JP4), (JP1 $\leftrightarrow \mathrm{JP} 4),(\mathrm{JHS} 1 \leftrightarrow \mathrm{JHS} 3)$, and (ET2 ↔ET3) should be correlated because they have high correlations, which would otherwise be jeopardized. The final measurement model consists of 52 items that were retained for subsequent analysis. As shown in Table 2 and Figure 2, all items have a loading of more than 0.50 and range from 0.666 to 0.968 . In terms of measurement values, all constructs achieved the minimum estimations required: 0.70 for Cronbach's alpha (Table 2), 0.50 for AVE, and 0.60 for CR.

Several relative tests were conducted to enable the measurement model to assess the validity of the proposed model. These tests include convergent validity and discriminant validity. In addition, Appendix F shows that the square root of AVE for all constructs is greater than correlations between this construct and other constructs in the model. Results also indicate that maximum shared squared variance is less 
than AVE. Appendix E also shows that results of the AVE test for all constructs were above the recommended value of .50 and ranged from 0.564 to 0.806 (Fronell \& Larcker, 1981).

Table 2: Factor Loading for CFA and Reliability Test Results

\begin{tabular}{|c|c|c|c|c|c|}
\hline Name of Construct & Dimension & $\begin{array}{l}\text { Number of } \\
\text { Items }\end{array}$ & Items & Loading & Cronbach's Alpha \\
\hline Job Performance & Job Performance & 12 & $\begin{array}{l}\text { JP1 } \\
\text { JP2 } \\
\text { JP3 } \\
\text { JP4 } \\
\text { JP5 } \\
\text { JP6 } \\
\text { JP7 } \\
\text { JP8 } \\
\text { JP9 } \\
\text { JP10 } \\
\text { JP11 } \\
\text { JP12 }\end{array}$ & $\begin{array}{l}0.713 \\
0.688 \\
0.716 \\
0.784 \\
0.853 \\
0.884 \\
0.885 \\
0.848 \\
0.852 \\
0.857 \\
0.882 \\
0.836\end{array}$ & 0.962 \\
\hline Turnover Intention & Intention & 6 & $\begin{array}{l}\text { ETI1 } \\
\text { ETI2 } \\
\text { ETI3 } \\
\text { ETI4 } \\
\text { ETI5 } \\
\text { ETI6 }\end{array}$ & $\begin{array}{l}0.800 \\
0.783 \\
0.711 \\
0.706 \\
0.702 \\
0.796\end{array}$ & 0.888 \\
\hline \multirow[t]{4}{*}{ Job Satisfaction } & Pay Satisfaction & 4 & $\begin{array}{l}\text { JSP1 } \\
\text { JSP2 } \\
\text { JSP3 } \\
\text { JSP4 }\end{array}$ & $\begin{array}{l}0.861 \\
0.859 \\
0.836 \\
0.856\end{array}$ & 0.924 \\
\hline & Supervisor Satisfaction & 4 & $\begin{array}{l}\text { JSS1 } \\
\text { JSS2 } \\
\text { JSS3 } \\
\text { JSS4 }\end{array}$ & $\begin{array}{l}0.853 \\
0.877 \\
0.903 \\
0.848\end{array}$ & 0.926 \\
\hline & Co-worker Satisfaction & 4 & $\begin{array}{l}\text { JSC1 } \\
\text { JSC2 } \\
\text { JSC3 } \\
\text { JSC4 }\end{array}$ & $\begin{array}{l}0.865 \\
0.863 \\
0.889 \\
0.902\end{array}$ & 0.932 \\
\hline & Promotion Satisfaction & 4 & $\begin{array}{l}\text { JSM1 } \\
\text { JSM2 } \\
\text { JSM3 } \\
\text { JSM4 }\end{array}$ & $\begin{array}{l}0.933 \\
0.968 \\
0.666 \\
0.686\end{array}$ & 0.901 \\
\hline \multirow[t]{3}{*}{ Job Happiness } & Optimism & 9 & $\begin{array}{c}\mathrm{JHO} 1 \\
\mathrm{JHO} 2 \\
\mathrm{JHO} 3 \\
\mathrm{JHO} 4 \\
\mathrm{JHO} 5 \\
\mathrm{JHO} 6 \\
\mathrm{JHO} 7 \\
\mathrm{JHO} 8 \\
\mathrm{JHO} 9\end{array}$ & $\begin{array}{l}0.895 \\
0.866 \\
0.866 \\
0.89 \\
0.88 \\
0.871 \\
0.862 \\
0.861 \\
0.872\end{array}$ & 0.967 \\
\hline & Social Relationships & 5 & $\begin{array}{l}\text { JHS1 } \\
\text { JHS2 } \\
\text { JHS3 } \\
\text { JHS4 } \\
\text { JHS5 }\end{array}$ & $\begin{array}{l}0.861 \\
0.882 \\
0.866 \\
0.895 \\
0.885\end{array}$ & 0.946 \\
\hline & Passive Moods & 4 & $\begin{array}{l}\text { JHP1 } \\
\text { JHP2 } \\
\text { JHP3 } \\
\text { JHP4 }\end{array}$ & $\begin{array}{l}0.912 \\
0.88 \\
0.899 \\
0.899\end{array}$ & 0.943 \\
\hline
\end{tabular}




\subsection{Structural model assessment}

A structural model assessment was conducted to examine the proposed hypothesis. This model has two independent variables: job satisfaction with four sub-dimensions (i.e., pay, supervisor, co-worker, and promotion satisfactions) and job happiness, which includes three sub-dimensions (i.e., optimism, social relationship, and passive moods). The variables of job performance and employee turnover intention comprise the dependent variables under study.

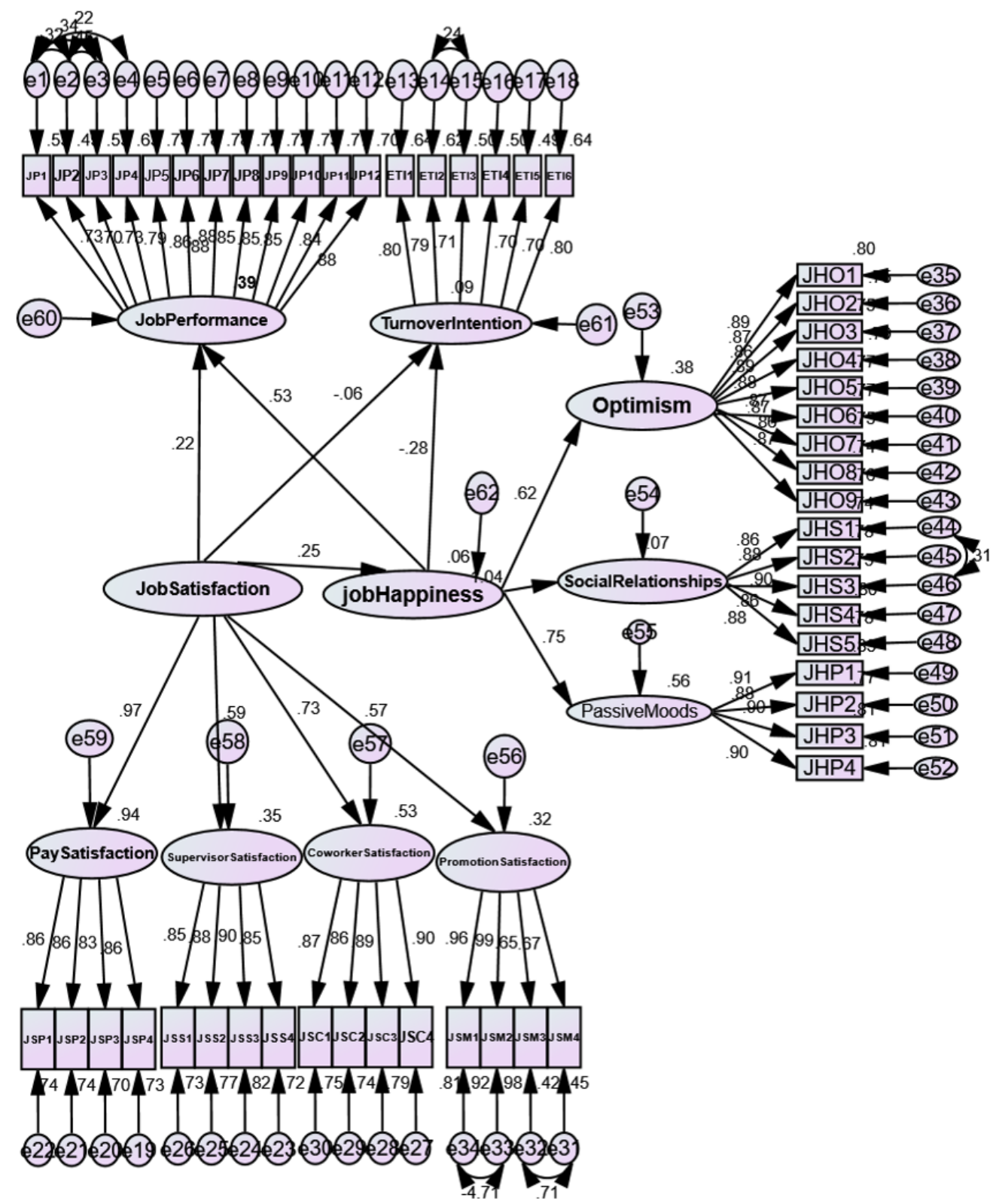

Figure 3: Structural model assessment

\subsubsection{Direct Effect Hypotheses}

Results in Table 3 indicate that job happiness has a strongly significant and positive effect on job performance among employees of the UAE oil and gas industry $(\beta=0.523 ; \mathrm{C} . \mathrm{R}=12.866 ; \mathrm{P}=0.000)$. Thus, H3 is supported. This result is consistent with the study of Oswald, Proto, and Sgroi (2014) who found that happy employees display enhanced motivation and that the health and well-being of employees and family are important factors that increase productivity. In other words, the happiest employees take a reduced number of leaves of absence and display loyal behavior for an extended period of time. These characteristics eventually improve the job performance of the workers. In essence, happiness at the 
workplace is a strong feeling associated with employees in which they feel proud of themselves, which results in improved performance in the organization (Daniels \& Harris, 2000).

Table 3 also shows that job happiness has a significant but negative effect on respondents with regard to turnover intention of employees in the UAE oil and gas industry $(\beta=-0.284 ; \mathrm{C} . \mathrm{R}=-6.856 ; \mathrm{P}=$ 0.000 ), thereby supporting H4. This result may be due to the fact that happiness or mental well-being has a collective effect on a number of factors that reduces turnover intention (Awang, Ibrahim \& Nor, 2015). For example, a happy employee has the potential to understand the goals and objectives of the organization and then continues positively, which contributes to the achievement of these goals.

Table 3 also indicates that job satisfaction has a significant and positive effect on job performance ( $\beta$ $=0.223 ; \mathrm{C} . \mathrm{R}=5.597 ; \mathrm{P}=0.000$ ). Thus, $\mathrm{H} 1$ is supported. This finding is consistent with many previous studies, such as those by Christen, Iyer, and Soberman (2006), Cook (2008), and Davar and Bala (2012), who found that job satisfaction plays a vital role in enhancing job performance of employees which, in turn, increases overall productivity of the business organization. Table 4.7 reveals that job satisfaction has a significant and positive influence on job happiness $(\beta=-0.252 ; C . R=5.445 ; P=0.000)$. Thus, H5 is supported.

Job satisfaction has an insignificant negative impact on the turnover intention ratio among employees of the UAE oil and gas industry $((\beta=-0.057$; C.R $=-1.362 ; \mathrm{P}=0.173)$. Thus, H2 is supported. This result is reinforced by previous studies, such as that of Medina (2012) who found that job satisfaction and turnover intention is inversely proportional to each other. Mahdi, Zin, Nor, Sakat, and Naim (2012) also investigated the relationship between job satisfaction and turnover intentions in Malaysian organizations. Their results also proved that an inverse relationship exists between job satisfaction and turnover intentions. Findings of the present study indicate that job satisfaction and job happiness have negative relationships with employee turnover intention. Therefore, the management of oil and gas organizations in the UAE should try formulating policies to help them keep employees happy and satisfied, which will ultimately help in employee retention.

Table 3: Direct Hypotheses Testing Results

\begin{tabular}{|c|c|c|c|c|c|c|c|}
\hline & Hypotheses & & Estimate &.$E$. &.$R$ & C-Value & Results \\
\hline 1 & Job Performance & $\begin{array}{l}\text { Job } \\
\text { Satisfaction }\end{array}$ & & 072 & .597 & $5_{* *}$ & Supported \\
\hline & Employee & Job & -.057 & & & - & Not \\
\hline 2 & $\begin{array}{l}\text { Turnover } \\
\text { Intention }\end{array}$ & Satisfaction & & 062 & 1.362 & 173 & Supported \\
\hline 3 & Job Performance & Job Happiness & & 041 & 2.866 & $1_{k *}$ & Supported \\
\hline 4 & $\begin{array}{l}\text { Employee } \\
\text { Turnover } \\
\text { Intention }\end{array}$ & Job Happiness & -.284 & 033 & 6.856 & - & Supported \\
\hline 5 & Job Happiness & $\begin{array}{l}\text { Job } \\
\text { Satisfaction }\end{array}$ & .252 & 086 & .445 & 5 & Supported \\
\hline
\end{tabular}

\subsubsection{Indirect Effect Hypotheses (Mediation Effect)}

Table 4 reveals that job satisfaction has significant indirect effects on job performance through its influence on job happiness, with an estimated coefficient of 0.243 . Therefore, job happiness plays a partial mediation role between job satisfaction and job performance. This finding is due to the fact that, as illustrated in Table 6, job satisfaction has significant direct effects on job happiness which also has a direct significant effect on job performance. The results in Table 6 show that job satisfaction has significant indirect negative effects on turnover intention through its influence on job happiness with a coefficient of -0.106. Therefore, job happiness plays a full mediation role between job satisfaction and turnover intention. This finding is due to the estimated coefficient of -0.057 , which indicates that the first direct relationship between job satisfaction and turnover intention is insignificant, but that the second and third ones are statistically significant. 
Table 4 Indirect Hypotheses Testing Results

\begin{tabular}{|c|c|c|c|c|c|}
\hline \multirow{3}{*}{ Hypotheses } & \multicolumn{3}{|c|}{ Direct Effect } & $\begin{array}{l}\text { Indirect } \\
\text { Effect }\end{array}$ & \multirow{3}{*}{ Results } \\
\hline & $\begin{array}{l}\text { First } \\
\text { Direct }\end{array}$ & $\begin{array}{l}\text { Second } \\
\text { Direct }\end{array}$ & $\begin{array}{l}\text { Third } \\
\text { Direct }\end{array}$ & \multirow[t]{2}{*}{ Coefficient } & \\
\hline & Coefficient & Coefficient & Coefficient & & \\
\hline $\begin{array}{l}\mathrm{H}_{6}: \text { Job Performance } \leftarrow \text { Job Satisfaction } \\
\text { through Job Happiness }\end{array}$ & $.223^{* * *}$ & $.225^{\star * *}$ & $.522^{* * * *}$ & $.243^{\text {**k* }}$ & $\begin{array}{l}\text { Partial } \\
\text { Mediating } \\
\text { Effect }\end{array}$ \\
\hline $\begin{array}{l}\mathrm{H}_{7} \text { : Employee Turnover Intention } \leftarrow \\
\text { Job Satisfaction through Job Happiness }\end{array}$ & -0.057 & $.225^{\star \star *}$ & $-.284^{* * *}$ & $-.106^{* \star *}$ & $\begin{array}{l}\text { Full } \\
\text { Mediating } \\
\text { Effect }\end{array}$ \\
\hline
\end{tabular}

Notes: ${ }^{* * *},{ }^{* *}$, and ${ }^{*}$ denote significance at the $1 \%, 5 \%$, and $10 \%$ level, respectively.

\section{Discussion}

The study found that job satisfaction has a significant positive effect on job performance indicating that the higher the salary is reasonable for the amount of work in the organization, supervisor praises people who do good work, relationships with other workers in this company are very good, and current job offers the right professional development opportunities to be effective in the job tasks, the more employees perform well because they receive the recognition for my efforts and always reach the targets at work. These results are consistent with previous studies (Spector, 2008; Davar and RanjuBala, 2011). However, this study found that job satisfaction has no significant effect on turnover intention which inconsistent which the previous studies (DeConinck \& Stilwell, 2004; O'Reilly et al., 2005) which they found that job satisfaction and turnover intention are negatively related to each other.

Further, job happiness which gound to have has a significant positive effect on job performance indicating that the higher the employees feel they have a great deal of energy, find beauty in some things, and find beauty in some things, the more employees perform well because they receive the recognition for my efforts and always reach the targets at work, which is consistent with previous studies (Daniels \& Harris, 2000).

In addition, this study found that job happiness has a negative influnce in turnover intention which is consistent with previous studies (Judge T. A., Thoresen, Bono \& Patton, 2001), which indicate that the higher the employees feel they have a great deal of energy, find beauty in some things, and find beauty in some things, the less they think of giving up the present job, and looking for another job soon. Moreover, this study found that job satisfaction indirectly influencing job performance and turnover intention through job happiness.

\section{Limitations and Suggestions for Future Work}

One of the limitations of this study is that the data gathered was cross-sectional rather than longitudinal in nature. The longitudinal method might improve the understanding of the associations and the causality between variables (Isaac, Abdullah, Ramayah, \& Mutahar, 2017; Isaac, Abdullah, Ramayah, Mutahar, \& Alrajawy, 2017; Isaac, Abdullah, Ramayah, \& Mutahar Ahmed, 2017). Future research should be conducted to investigate the relationship between variables by conducting cross-cultural studies as recommended by previous studies (Isaac, Abdullah, Ramayah, \& Mutahar, 2017a; Isaac, Abdullah, Ramayah, \& Mutahar, 2017b; Isaac, Masoud, Samad, \& Abdullah, 2016).

\section{Conclusion and Recommendation}

Organizations should increase spending on research and development in order to increase the organizational effectiveness (Osama Isaac, Abdullah, Ramayah, Mutahar, \& Alrajawy, 2018; Osama Isaac, Abdullah, Ramayah, \& Mutahar, 2018). This study utilized SEM to examine factors that influence performance and turnover intentions of employees in the UAE oil and gas industry. This study examined the role of the mediating effect of job happiness between job satisfaction and performance and turnover intentions of employees in the oil and gas industry in the UAE. Data were randomly collected from 722 employees. Results revealed that job satisfaction has a positive significant influence on employee performance and an insignificant influence on turnover intention. Job happiness also has a direct 
significant influence on employee job performance and turnover intention. Findings also indicate that job happiness plays a full mediation role between job satisfaction and turnover intention and a partial mediation role between job satisfaction and job performance. Thus, organization managements or human resource departments in the oil and gas industry in the UAE should consider the effect of the mediating role of job happiness (mental well-being) as an indicator for improving and predicting employee performance and for reducing turnover intention ratios.

This study focused only on the oil and gas industry in the UAE. Therefore, generalizing results of the current study to other industries in the UAE is inappropriate. Increasing the sample size of the study to include other industries in UAE may provide additional comprehensive and validation results that illustrate a highly realistic picture about the behavior of organizations and their employees.

\section{References}

Abd-Elaziz, M. E., Aziz, W. M., Khalifa, G. S., \& Abdel-Aleem, M. (2015). Determinants of Electronic word of mouth (EWOM) influence on hotel customers' purchasing decision. Journal of Faculty of Tourism and Hotels, Fayoum University, 9(2/2), 194-223.

Abdulbaqi Ameen, A., \& Ahmad, K. (2011). The role of Finance Information Systems in anti financial corruptions: A theoretical review. In 2011 International Conference on Research and Innovation in Information Systems, ICRIIS'11 (pp. 1-6). Ieee. http:// doi.org/10.1109/ICRIIS.2011.6125725

Adel Haddad, Ali Abdulbaqi Ameen, \& Muaadh Mukred. (2018). The Impact of Intention of Use on The Success of Big Data Adoption Via Organization Readiness Factor. International Journal of Management and Human Science, 2(1), 43-51. Retrieved from http://www.ijmhs.org/index.aspx

Alexander, J. A., Liechtenstein, R. O., \& Hellmann, E. (1998). A causal model of voluntary turn-over among nursing personnel in long term psychiatric setting. Research in Nursing and Health, 21, 415-427.

Al-Maamari, Q. A., Muhammed Kassim, R.-N., Raju, V., Al-Tahitah, A., Ameen, A. A., \& Abdulrab, M. (2018). Factors Affecting Individual Readiness for Change: A Conceptual Framework. International Journal of Management and Human Science, 2(1), 13-18. Retrieved from http://www.ijmhs.org/index.aspx

Al-Obthani, F., \& Ameen, A. (2018). TOWARDS CUSTOMIZED SMART GOVERNMENT QUALITY MODEL. International Journal of Software Engineering \& Applications (IJSEA), 9(2), 41-49. http://doi.org/10.5121/ijsea.2018.9204

Ameen, A. A., \& Ahmad, K. (2012). Towards Harnessing Financial Information Systems in Reducing Corruption : A Review of Strategies. Australian Journal of Basic and Applied Sciences, 6(8), 500-509.

Ameen, A., Almulla, A., Ali, M., Al-shibami, A. H., \& Ghosh, A. (2018). The Impact of Knowledge Sharing on Managing Organizational Change within Abu Dhabi National Oil Organizations. Nternational Journal of Management and Human Science (IJMHS), 2(3), 27-36.

Argyle, M. (1989). Do happy workers work harder? The effect of job satisfaction on work performance. How harmfull is happiness, 94-105.

Awang, Z. (2014). Structural Equation Modeling Using AMOS. Shah Alam.Malaysia: University Teknologi MARA Publication Center.

Bentler, P. M., \& G.Bonnet, D. (1980). Significance tests and goodness of fit in the analysis of covariance structures. Psychological Bulletin, 88(3), 588-606.

Bollen, K. A. (1990). Overall fit in covariance structure models: Two types of sample size effects. Psychological Bulletin, 107(2), 256-259.

Byrne, B. M. (2010). Structural Equation Modeling With AMOS: Basic Concepts, Applications, and Programming (2nd ed.). Routledge.

Carmeli, D. (1991). Involuntary retirement, type A behavior, and current functioning in elderly men: 27-year followup of the Western Collaborative Group Study. Psychology and Aging, 6, 384-391.

Christen, M., Iyer, G., \& Soberman, D. (2006). Job Satisfaction, Job Performance,and Effort: A Reexamination Using Agency Theory. American Marketing Association, 70, 137-150.

Cook, A. L. (2008). Job satisfaction and job performance: is the relationship spurious? (Doctoral dissertation, Texas A\&M University).

Cook, D. (2015). The happiness factor in job satisfaction. Retrieved January 05, 2016, from http://www.benefitspro.com/2015/12/03/the-happiness-factor-in-job-satisfaction.

Costello, A. B., \& Osborne, J. W. (2005). Best practices in exploratory factor analysis: Four recommendations for getting the most from your analysis. Practical Assessment, Research and Evaluation, 10(7), 1-9.

Daniels, K., \& Harris, C. (2000). Work, psychological well-being and performance. Occupational Medicine, 50(5), 304309. 
Daniels, K., \& Harris, C. (2000). Work, psychological well-being and performance. Occupational Medicine, 50(5), 304309.

Davar, S. C., \& RanjuBala. (2011). Relationship between Job Satisfaction \& Job Performance: A Meta-Analysis. Indian Journal of Industrial Relations, 48(2), 290-305.

DeConinck, J.B. \& Stilwell, C.D.(2004). Incorporating organizational justice, role states, pay satisfaction and supervisor in a model of turnover intention. Journal Business Reviews, 57,225-231.

Fatah, Kamal Abdel, a Kamal Abdel Fatah, A. A. A. A. (2017). Toward Harnessing Reengineering as a Tool for the Development of Public Organizations: A Theoretical Abstraction. In 1st International Conference on Management and Human Science 2017.

Field, A. (2013). Discovering Statistics Using IBM SPSS Statistics (4th ed.). SAGE Publications Ltd.

Fornell, C., \& Larcker, D. (1981). Structural equation models with unobservablevariables and measurement error: Algebra and statistics. Journal of Marketing Research, 18(3),382-388.

Govender, D. M. (2014). An investigation into job satisfaction and employee performance at Stodels Retail Nurseries: a case study (Doctoral dissertation).

Guest DE (2004). Flexible employment contracts, the psychological contract and employee outcomes. An analysis and review of the evidence. Int. J. Manage. Rev., 5/6 (1): 1-19.

Hair, J. F., Anderson, R. E., Black, W. B., \& Tatham, R. L. (2010). Multivariate Data Analysis:PrenticeHall.

Hair, J. F., Anderson, R. E., Black, W. B., Babin, B., \& Tatham, R. L.(2006). Multivariate Data Analysis. Auflage, Upper saddle river. (Seven, Ed.).

Hair, J. F., Anderson, R. E., Tatham, R. L. \& Black, W. C. (1998). Multivariate Data Analysis (5th ed.), New Jersey, Prentice-Hall.

Hu, L., \& Bentler, P. M. (1999). Cutoff criteria for fit indexes in covariance structure analysis: Conventional criteria versus new alternatives. Structural Equation Modeling, 6, 1-55.

Hutcheson, G. D., \& Sofroniou, N. (1999). The multivariate social scientist. London: Sage.

Isaac, O., Abdullah, Z., Ramayah, T., \& Mutahar Ahmed, M. (2017). Examining the Relationship Between Overall Quality, User Satisfaction and Internet Usage: An Integrated Individual, Technological, Organizational and Social Perspective. Asian Journal of Information Technology, 16(1), 100-124. http://doi.org/10.3923/ajit.2017.100.124

Isaac, O., Abdullah, Z., Ramayah, T., \& Mutahar, A. M. (2017). Internet usage, user satisfaction, task-technology fit, and performance impact among public sector employees in Yemen. International Journal of Information and Learning Technology, 34(3), 210-241. http://doi.org/10.1108/IJILT-11-2016-0051

Isaac, O., Abdullah, Z., Ramayah, T., \& Mutahar, A. M. (2017a). Internet Usage and Net Benefit among Employees Within Government Institutions in Yemen: An Extension of Delone and Mclean Information Systems Success Model (DMISM) with Task-Technology Fit. International Journal of Soft Computing, 12(3), 178-198. http://doi.org/10.3923/ijscomp.2017.178.198

Isaac, O., Abdullah, Z., Ramayah, T., \& Mutahar, A. M. (2017b). Internet Usage within Government Institutions in Yemen: An Extended Technology Acceptance Model (TAM) with Internet Self-Efficacy and Performance Impact. Science International, 29(4), 737-747.

Isaac, O., Abdullah, Z., Ramayah, T., \& Mutahar, A. M. (2018). Factors determining user satisfaction of internet usage among public sector employees in Yemen. International Journal of Technological Learning, Innovation and Development, 10(1), 37-68. http://doi.org/10.1504/IJTLID.2018.10012960

Isaac, O., Abdullah, Z., Ramayah, T., Mutahar, A. M., \& Alrajawy, I. (2017). Towards a Better Understanding of Internet Technology Usage by Yemeni Employees in the Public Sector: An Extension of the Task-Technology Fit (TTF) Model. Research Journal of Applied Sciences, 12(2), 205-223. http:/ / doi.org/10.3923/rjasci.2017.205.223

Isaac, O., Abdullah, Z., Ramayah, T., Mutahar, A. M., \& Alrajawy, I. (2018). Integrating User Satisfaction and Performance Impact with Technology Acceptance Model (TAM) to Examine the Internet Usage Within Organizations in Yemen. Asian Journal of Information Technology, 17(1), 60-78. http:/ / doi.org/10.3923/ajit.2018.60.78

Isaac, O., Abdullah, Z., Ramayah, T., Mutahar, A. M., \& Alrajawy, I. (2017). Towards a Better Understanding of Internet Technology Usage by Yemeni Employees in the Public Sector: An Extension of the Task-Technology Fit (TTF) Model. Research Journal of Applied Sciences, 12(2), 205-223. http:/ / doi.org/10.3923/rjasci.2017.205.223

Isaac, O., Masoud, Y., Samad, S., \& Abdullah, Z. (2016). The mediating effect of strategic implementation between strategy formulation and organizational performance within government institutions in Yemen. Research Journal of Applied Sciences, 11(10), 1002-1013. http:/ / doi.org/10.3923/rjasci.2016.1002.1013 
Isaac, O., Masoud, Y., Samad, S., \& Abdullah, Z. (2016). The mediating effect of strategic implementation between strategy formulation and organizational performance within government institutions in Yemen. Research Journal of Applied Sciences, 11(10), 1002-1013. http:/ / doi.org/10.3923/rjasci.2016.1002.1013

James, L. R., Muliak, S. A., \& Brett, J. M. (1982). Causal analysis: Models, assumptions and data. Beverly Hills, CA: Sage.

Jöreskog, K., \& Sörbom, D. (1993). LISREL 8: Structural Equation Modeling with the SIMPLIS Command Language. Chicago: IL: Scientific Software International Inc.

Judge, T. A., Thoresen, C. J., Bono, J. E., \& Patton, G. K. (2001). The Job Satisfaction-Job Performance Relationship:A Qualitative and Quantitative Review. Psychological Bulletin, 127(3), 376-407.

Kaiser, H. F. (1974). An index of factorial simplicity. Psychometrika, 39, 31-36.

Kessler, L. L. (2014). The effect of job satisfaction on IT employee's turnover intention in Israel. THE ANNALS OF THE UNIVERSITY OF ORADEA, 1026.

Khan, A. H., Nawaz, M. M., Aleem, M., \& Hamed, W. (2012). Impact of job satisfaction on employee performance: An empirical study of autonomous Medical Institutions of Pakistan. African Journal of Business Management, 6(7), 2697.

Kline, R. B. (2010). Principles and practice of structural equation modeling (3rd ed.). New York: The Guilford Press.

Kline, R.B. (2005), Principles and Practice of Structural Equation Modeling (2nd Edition ed.). New York: The Guilford Press.

Lee, K. S., \& Kim, S. Y. (2007). Factors influencing the adoption behavior of mobile banking. A South Korean perspective. Journal of Internet Banking and Commerce, 12(2), 1-9.

Mahdi, A. F., Zin, M. Z., Nor, M. R., Sakat, A. A., \& Naim, A. S. (2012). The Relationship Between Job Satisfaction and Turnover Intention. American Journal of Applied Sciences, 9(9), 1518-1526.

Medina, E. (2012). Job Satisfaction and Employee Turnover Intention: What does Organizational Culture Have to Do with It? Master's theses, Department of Quantitative Methods in the Social Sciences, Columbia University, New York.

O’Reilly, R. C., Frank, M. J., Hazy, T. E., \& Watz, B. (2005). Rewards are timeless: The primary value and learned value (PVLV) Pavlovian learning algorithm. Manuscript submitted for publication.

Opkara JO (2002). The Impact of Salary Differential on Managerial Job Satisfaction. A Study of The Gender Gap and Its Implications For Management Education And Practice In A Developing Economy. J. Bus. Dev. Nation, 6592.

Podsakoff, P. M., \& Organ, D. W. (1986). Self-reports in organizational research: Problems and prospects. Journal of Management, 12(4), 531-544.

Rashed Shtait Hamad AlShamsi, Ali Ameen, A. H. A.-S. (2017). The Influence of Smart Government on Happiness: Proposing Framework. In 1 st International Conference on Management and Human Science (ICMHS 2017) (p. 2017).

Salmeen Al-Obthani, F., \& Abdulbaqi Ameen, A. (2018). TOWARDS CUSTOMIZED SMART GOVERNMENT QUALITY MODEL. International Journal of Software Engineering \& Applications (IJSEA), 9(2), 41-49. http:/ / doi.org/10.5121/ijsea.2018.9204

Schermerhorn J, Hunt J, Osborn R (2005). Organizational Behavior (9th ed.): John Wiley. New York. NY.

Schumacker, R. E., \& Lomax, R. G. (2004). A beginner's guide to structural equation modeling. Psychology Press.

Silla I, Gracia F, Peiro JM (2005). Job insecurity and health-related outcomes among different types of temporary workers. Econ. Ind. Democracy, 26: 89-117.

Spector P (2008). Industrial and Organizational Psychology. Research and Practice, 5th ed., John Wiley \& Sons, New York, NY.

Steiger, J. H. (1990). Structural model evaluation and modification: An interval estimation approach. Multivariate Behavioral Research, 25 (2), 173-180.

Tabachnick, B. G., \& Fidell, L. S. (2007). Using Multivariate Statistics. PsycCRITIQUES, 28, 980. http://doi.org/10.1037/022267

Tucker, L. R., \& Lewis, C. (1973). A reliability coefficient for maximum likelihood factor analysis. Psychometrika, 38(1), 1-10.

Vroom, V. H. (1964). Work and motivation. New York: Wiley.

Wright, T. A., \& Cropanzano, R. (2004). The Role of Psychological Well-Being in Job Performance: A Fresh Look at an Age-Old Quest. Organizational Dynamics, 33(4), 338-351.

Wright, T. A., Cropanzano, R., \& Meyer, D. G. (2004). State and trait correlates of job performance: A tale of two perspectives. Journal of Business and Psychology, 18(3), 365-383.

Wu, X. (2012). Factors Influencing Employee Turnover Intention: The Case of Retail Industry in Bangkok, Thailand (Doctoral dissertation, University of the Thai Chamber of Commerce). 